\title{
EVALUATION OF CARBOFURAN FOR THE CONTROL OF SOLDIER FLY IN PASTURE
}

\author{
A. G. MACKAY, G. R. ROWE and N. C. GUTHRIE \\ ICI New Zealand Limited, Hamilton
}

Summary

The first of a succession of trials was commenced at Raglan in 1973 to study the effect of under-drilling the insecticide carbofuran with ryegrass seed into land infested with soldier fly larvae. Carbofuran $2 \mathrm{~kg} / \mathrm{ha}$ resulted in a highly significant $(1 \%$ level) reduction in soldier fly (Inopus rubriceps) larvae 3 and 12 months after application and a similar increase in total dry matter measured at six separate harvests during that year. A combination of a pre-sowing application of paraquat followed by carbofuran signifrantly (1\% level) reduced the soldierfly larvae numbers in comparison with all other treatments 3 and 12 months after application.

\section{INTRODUCTION}

The pest status of soldier fly (Inopus rubriceps) in Australia and New Zealand has been well documented (Saunders, 1963; Hitchcock, 1970; Hewitt, 1969 and Wilcocks, 1974). Present control methods involving surface cultivation (Wilcocks and Hewitt, 1971; Dixon and Grimmer, 1973, and Cumberland et al, 1973) have been shown to reduce larval numbers. Such methods are however considered to be expensive and are advocated as a last resort (Wilcocks, 1974). Due largely to the high rates required, early workers considered that chemical control of soldier fly in pastures would also prove expensive (Dumbleton, 1949; Saunders, 1963; Hewitt, 1964, 1969 and Cumberland and Honore 1973). In a pasture screening trial Dixon and Grimmer (1973) reported a promising kill of larvae from the systemic insecticides carbofuran $(93 \%)$ phorate $(76 \%)$ and fenamiphos $(71 \%)$. They considered that these materials would warrant further consideration as a possible means of controlling soldier fly.

In May of 1973 a series of trials was initiated at Raglan to study the effect of underdrilling the insecticide carbofuran together with gras seed into land infested with soldier fly larvae.A randomised block design trial was sited at Raglan, Waikato on a clay loam and the treatments shown in Table 2, were replicated 5 to 6 times on plots $10 \times 2.6 \mathrm{~m}$. Treatments were applied on the 31 st May, 1973 with a Duncan triple disc "Multiseeder drill" in $15 \mathrm{~cm}$ rows with serpentine superphosphate drilled at a rate of $1000 \mathrm{~kg} / \mathrm{ha}$ on all plots. Carbofuran as $5 \%$ granules was mixed and drilled with fertiliser. The grass seed mixture used in the trial was $11 \mathrm{~kg} / \mathrm{ha}$ of perennial and $5.5 \mathrm{~kg} / \mathrm{ha}$ of short rotation ryegrass (Lolium spp.). Treatments 2 and 4 were sprayed with paraquat $0.6 \mathrm{~kg}$ in 500 litres/ha on the 28th May 1973.

\section{Larvae Assessment}

Treatment effect on the soil population of soldier fly was measured by taking eight random $8 \mathrm{~cm}$ diameter soil cores to a depth of $10 \mathrm{~cm}$ per plot and counting the larvae. Larval assessment was carried out before treatment and 2,3 and 12 months post-treatment.

The effect of paraquat and carbofuran on the larval population was measured 2 months after treatment. Eight soil cores were taken at random on the $15 \mathrm{~cm}$. rows of treatments 2 and 4 and a similar 
number of cores taken between the rows for larvae assessment. A standard sieve and floatation technique involving the use of magnesium sulphate and water was used in these procedures.

\section{Plant Assessment}

The effect of soldier fly and treatment on ryegrass seedling emergence was assessed by counting the number of : seedlings present in twelve $1 \mathrm{~m}$ lengths of row in each of the non carbofuran treated plots and four $1 \mathrm{~m}$ length of row in the carbofuran treated plots.

Plant vigour was assessed by four independent observers on the 1st August 1973. The visual scale used to assess treatment response was as follows:

$$
\begin{aligned}
& \mathbf{1}=\text { no pasture growth response } \\
& \mathbf{5}
\end{aligned}
$$

Pasture production was measured at six intervals during the year. A randomly selected area of $5 \mathrm{~m}^{2}$ was harvested from each plot for dry matter and herbage composition determination. After each harvest the area was heavily block grazed with sheep and closed for the next assessment.

\section{RESULTS}

Soldier fly larvae numbers: $\begin{gathered}\text { (Divide larvae counts by } 36.5 \text { to get } \\ 1000 \mathrm{~s} / \mathrm{m}^{2} \text { ) }\end{gathered}$

TABLE 1: THE EFFECT OF CARBOFURAN ON SOLDIER FIY

LARVAE UNDER NEW PASTURE ESTABLISHED WITH THE AID OF PARAQUAT SIX WEEKS AFTER TREATMENT

\begin{tabular}{lc}
\hline Treatment & Mean larvae per treatment \\
\hline paraquat+seed & $425 \mathrm{aA}$ \\
paraquat+seed+carbofuran $2 \mathrm{~kg} / \mathrm{ha}$ & $31 \mathrm{bB}$ \\
CV\% & 20
\end{tabular}

A highly significant reduction in the number of larvae was measured on the carbofuran treatment (Table 1).

TABLE 2: THE EFFECT OF TREATMENT ON NUMBER OF SOLDIER FLY LARVAE AND PASTURE VIGOUR

\begin{tabular}{|c|c|c|c|}
\hline Treatment & $\begin{array}{l}3 \text { months }^{*} \\
\text { mean larvat no. }\end{array}$ & $\begin{array}{l}12 \text { months } \\
\text { mean larvae }\end{array}$ & $\begin{array}{l}2 \text { months } \\
\text { No. pasture vigour }\end{array}$ \\
\hline $\begin{array}{l}\text { seed } \\
\text { paraquat }+ \text { seed } \\
\text { carbofuran } 2 \mathrm{~kg} / \mathrm{ha}+\text { seed } \\
\text { paraquat }+ \text { carbofuran } 2 \mathrm{~kg} / \mathrm{ha} \\
\text { undersow carbofuran } 2 \mathrm{~kg} / \mathrm{ha}\end{array}$ & $\begin{array}{l}297 \mathrm{abA} \\
269 \mathrm{bA} \\
1.18 \mathrm{cB} \\
50 \mathrm{dC}\end{array}$ & $\begin{array}{c}63 \mathrm{aAB} \\
55 \mathrm{aAB} \\
24 \mathrm{bBC} \\
5 \mathrm{cD}\end{array}$ & $\begin{array}{l}1.7 \mathrm{bB} \\
1.3 \mathrm{bB} \\
4.4 \mathrm{aA} \\
4.6 \mathrm{aA}\end{array}$ \\
\hline $\begin{array}{l}\text { (no seed) } \\
\text { control } \\
\text { CV\% }\end{array}$ & $\begin{array}{r}144 \mathrm{cB} \\
358 \mathrm{aA} \\
27\end{array}$ & $\begin{array}{l}17 \mathrm{bC} \\
75 \mathrm{aA} \\
54\end{array}$ & $\begin{array}{l}4.4 \mathrm{aA} \\
1.6 \mathrm{bB} \\
14\end{array}$ \\
\hline Main Effects. & uat $\quad \begin{array}{l}\mathbf{A A} \\
\mathbf{b B}\end{array}$ & $\begin{array}{l}\text { no carbofura } \\
\text { carbofuran }\end{array}$ & $\begin{array}{ll}\mathrm{aA} & \mathrm{bA}\end{array}$ \\
\hline
\end{tabular}

* the 3 month treatment means have been adjusted for co-variance. 
Three month assessment:

Carbofuran $2 \mathrm{~kg} / \mathrm{ha}$ significantly reduced the number of larvae in comparison with all other treatments (Table 2) and pre-treatment with paraquat gave a further significant reduction. In comparison with control a significant reduction in the number of larvae occurred when paraquat was used as an aid to pasture establishment.

Twelve months assessment

The same superiority of paraquat and carbofuran was shown as at the three month assessment. The carbofuran effect on larvae numbers was stronger than the paraquat effect.

Both on and between the row carbofuran caused a highly significant reduction of larvae numbers $(1 \%$ level) (Table 3$)$. With paraqua ${ }^{\dagger}$ a one larvae numbers between the row were significantly lower than those on the row.

TABLE 3: NUMBER OF SOLDIER FLY LARVAE ASSESSED ON AND BETWEEN THE $15 \mathrm{~cm}$ DRILLED ROW TWO MONTHS AFT R TREATMENT AND NUMBER OF RYEGRASS SEEDLINGS PRESENT SIX WEEKS AFTER TREATMENT

\begin{tabular}{lccc}
\hline Treatment & \multicolumn{2}{c}{$\begin{array}{c}\text { Mean Larvae No.* } \\
\text { on row between rows }\end{array}$} & $\begin{array}{c}\text { Mean No. Seedlings/ } \\
\text { on row } t\end{array}$ \\
\hline paraquat pre-sowing + seed & $331 \mathrm{aA}$ & $211 \mathrm{bB}$ & $40 \mathrm{a}$ \\
paraquat pre-sowing + seed & & & \\
$\begin{array}{l}+ \text { carbofuran } 2 \mathrm{~kg} / \mathrm{ha} \\
\text { CV } \%\end{array}$ & $33 \mathrm{cC}$ & $60 \mathrm{cC}$ & $48 \mathrm{a}$ \\
\hline
\end{tabular}

* The interaction is significant at $1 \%$

$\dagger$ Minimum significant difference $=11$

Dry matter production

Table 4 summarises the dry matter production measured within the period 31 May 1973 to 16 May 1974.

At the 3 September and 12 October 1973 cuts a significant response in ryegrass and clover production was measured from the addition of carbofuran $2 \mathrm{~kg} / \mathrm{ha}$. Similarly a significant decline in both ryegrass and clover was measured on paraquat treatments.

At the 16 November 1973 cut a significant increase in drvmatter was measured on the carbofuran treated plots in comparison with all other treatments. At this harvest drvmatter producion on the carbofuran and paraquat treatments did not differ significantly from the carbofuran alone. The interaction between carbofuran and paraquat on drymatter production was significant at the $1 \%$ level.

Carbofuran recorded a significant response in dry matter production in comparison with all other treatments on 31 January, 3 April and 16 May 1974.

Without carbofuran paraquat significantly $(5 \%$ level) reduced total dry matter in comparison with untreated on 16 May 1974.

During the full year of treatment all treatments with carbofuran significantly increased dry matter production. Paraquat reduced dry matter production but the interaction between carbofuran and paraquat was significant.

Additional work

Further experiments gave similar statistically significant responses in terms of reduction in larvae numbers and increased production. (Mackay, Rowe et al, 1974). 
Pasture Pests

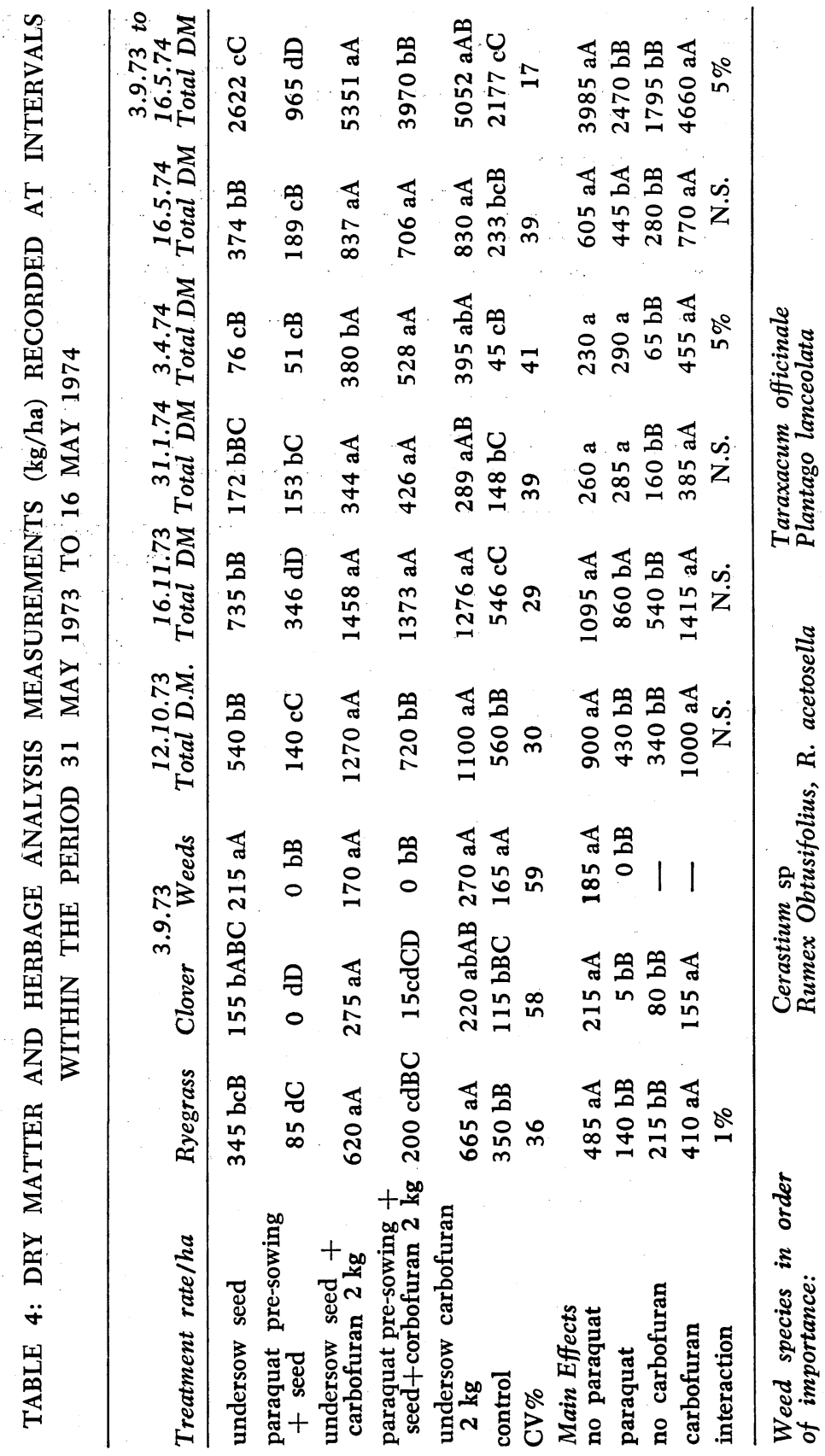

218 


\section{DISCUSSION}

Research in New Zealand has investigated three main techniques for the control of soldier fly, these are:

(a) Pasture trampling under heavy winter stocking rates which was found to be only: partially effective (Wilcocks 1971).

(b) Cultivation: (Wilcocks and Hewitt 1971) showed that 13 cultivations in the autumn caused a $95 \%$ reduction in larvae numbers, whilst a continuous cultivation treatment (between February and May) reduced larval number by $(75-90 \%)$ and increased dry matter production (Cumberland, 1973).

(c) Chemical.

At current agricultural contracting rates of $\$ 10$ per hour, the cost of cultivation is approximately $\$ 90$ per hectare for a total of nine cultivations, compared with thirteen cultivations described by Wilcocks and Hewitt (1971). These costs do not take into account the interim loss of dry matter production during the establishment period required for new pasture.

Cultivation also destroys the clover component of the original pasture, resulting in a reduction of available nitrogen to the developing sward.

The experimental evidence presented in this paper has shown that undersowing carbofuran into land infested with soldier fly caused a significant reduction in the larvae population and increase in dry matter production. Measurements of these responses, which have persisted for a year after treatment, are being continued.

\section{BETWEEN ROW \& ONROW}

COMPARISON

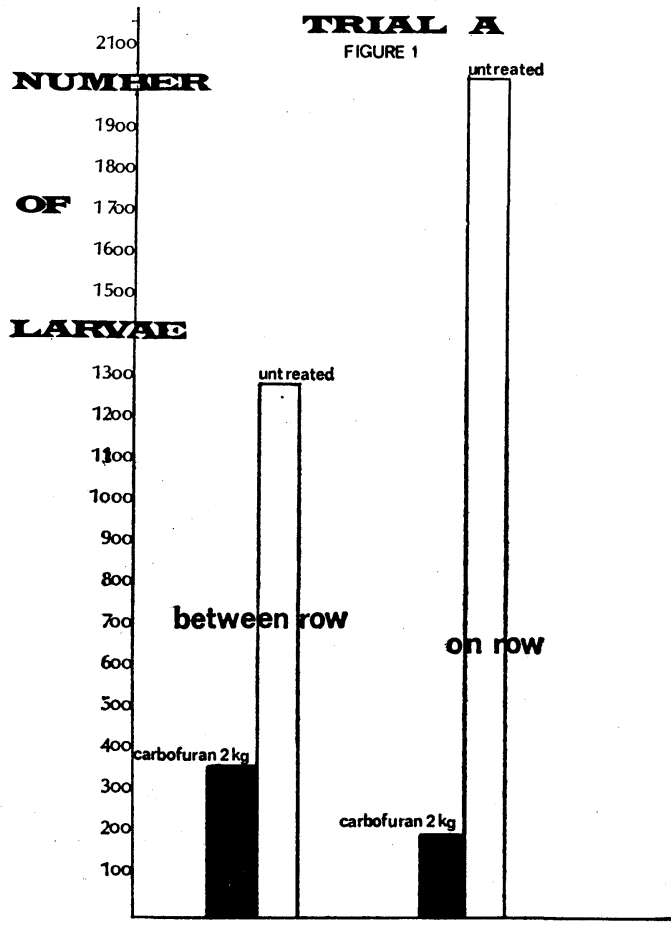




\section{Pasture Pests}

In practice the results obtained in the trials may be applied in a number of ways. If the larvae infestation is relatively light (3000-6000 $/ \mathrm{m}^{2}$ ) one of the first indications of an insect problem is a noticeable loss of ryegrass from the sward. In this situation undersowing with $2 \mathrm{~kg} / \mathrm{ha}$ of carbofuran can reduce the number of larvae present in the soil for more than 12 months. A substantial dry matter production increase has been shown to result from this treatment. If however, the pasture has deteriorated to the stage where the ryegrass is almost absent from the sward, undersowing with seed and carbofuran can reduce larvae numbers and increase pasture production. In land which is so heavily infested with soldier fly, $\left(10,000-13,000 / \mathrm{m}^{2}\right)$ that all grass has been lost from the swar 7 , leaving only weed species and clover, the use of paraquat as a pre-sowing spray prior to under-drilling with seed and carbofuran may be recommended. The combined effect of paraquat and carbofuran on the larvae of soldier fly both on and between the drilled row indicates that the paraquat treatment which effectively kills the existing pasture sward, may encourage larvae movement towards a new food source, i.e. the developing ryegrass seedlings (Fig. 1). The fact that this treatment resulted in the greatest reduction in larvae numbers warrants further research.

Seedling emergence was not significantly affected by the soldierfly larvae. Dixon (pers. comm.) in small pot work has confirmed this effect bv germinating ryegrass in the presence of high populations of soldier fly. The significant differences in ryegrass production which were measured suggest that the soldier fly larvae may affect plant vigour reducing the future tillering capacity of the seedling ryegrass.

\section{ACKNOWLEDGEMENTS}

The authors wish to acknowledge the assistance of farmers Messrs Lusty and Peart for trial sites; C. B. Dvson, biometrician Ministry of Agriculture and Fisheries, Ruakura, for the analysis of the results obtained for this report, W. F. Leonard and P. C. Palmer of Agricultural Division, ICI New Zealand Ltd, for their support and assistance with many matters.

\section{REFERENCES}

Cumberland, G. L. B., Dyson, C. B., Farrel, C. A., 1973. Soldier fly aspects of its control with autumn cultivation. Proc. 26 th N.Z. Weed and Pest Control Conf.: 196-200.

Cumberland, G. L. B., Honore, E. N., 1973. Soldier flv $-\operatorname{con}^{+r o}{ }^{1}$ of larvae with chemicals. Proc. 26th N.Z. Weed and Pest Control Conf: 210-11.

Dixon, G. M., Grimmer, D. C., 1973. The potential of insecticides as a means of controlling soldier fly (Inopus rubriceps) (Marquart). Proc. 26th N.Z. Weed and Pest Control Conf. 201-5.

Dumbleton, L. T., 1949. The economic status of Metoponia rubriceps (Macquart). N.Z. Journal of Science and Technology 30 (8): 224-32.

Hewitt, S. R., 1964. Trials on soldier fly. Proc. 17th N.Z. Weed and Pest Control Conf. 191-6.

Hewitt, S. R., 1969. The effect of Australian soldier fly on nasture crops and production. Proc. 22nd N.Z. Weed and Pest Control Conf. 280-6.

Hitchcock, B. E., 1970. The soldier fly pest. Proceedings of the Conference of Queensland Society of Sugar Cane Technologists: 206-16.

Mackay, A. G., Rowe, G. R. and Gutherie, N. C., 1974. N.Z. Exp. Agriculture (in press). 
Saunders, G. W., 1963. Soldier fly (Atermetoponia rubriceps) attacks Atherton Tableland pastures. Queensland Agricultural Journal 89 (4): $217-9$.

Wilcocks, C. R., 1971. Review of control measures for the Australian soldier fly. Proc. 24th N.Z. Weed and Pest Control Conf.: 155-9.

Wilcocks, C. R., Hewitt, S. R., 1971. Estimation of the effectiveness of autumn surface cultivation for the control of the Australian soldier fly. Proc. 24th. N.Z. Weed and Pest Control Conf. 160-3.

Wilcocks, C. R., 1974: The soldierfly problem. N.Z.J. Exp. Agr. Vol 2.

(Chairman's Summary continued)

no critical work had been done. In reply to a question from $\mathrm{Mr}$ Lynch as to what he meant by a "normal pasture mix" Mr Farrell stated that it would be more correct to say that the same seeds mixture had been used in all trial work.

Carbofuran appeared to be the most promising chemical for control of soldier fly and questions were raised as to its possible effects on earthworms. This aspect was receiving attention but had not yet been completed. In reply to a question as to whether some of the effect on pasture growth could be due to factors other than effects on soldier fly larvae, Dr Parle stated that Mr Dixon had been unable to produce any. plant growth effects in the absence of soldier fly in pot experiments. Mr Proude pointed out that the few promising insecticides against soldier fly were in fact all systematic nematicides. This could be significant.

Sowing insecticides in with seed evidently improved effectiveness and the question arose as to whether larvae were attracted to the roots of plants or whether the chemicals themselves might be attractive. It was stated that soldier fly larvae did appear to be attracted and that they might be more mobile than originally believed.

Mr King's paper on black beetle reported considerably improved effectiveness of ceriain insecticides in peat soils when drilled into the pasture surface compared to surface broadcast. The drilling procedure however caused some mechanical damage. It was suggested that the Duncan Multiseeder might be considered as a possible implement as it caused very little pasture damage. Mr Leonard commented that there could be other advantages in putting insecticide beneath the pasture surface besides improved performance, such as reduced hazard to birds.

Mr King stated that it seemed that unlike grass grub, black beetle larvae were not selective feeders and were not attracted to the roots of particular plants. Effects of narrow band treatment with insecticide were thought to be produced by random movement of larvae.

In closing the session the Chairman commented that the papers presented illustrated well the procedures involved in evaluation of new chemicals for pasture pest control; initial screening to detect the most active materials for the pest in question, investigation of formulation and methods of application for optimum effect; and integration of chemical controls together with other pasture manipulation procedures.

Proc. 27th N.Z.: Weed and Pest Control Conf. 